\title{
A critical discourse analysis of selected news reports of South Africa xenophobic attacks of Nigerians
}

\author{
OYEDEJI Gideon Abioye* and IDRIS Nabila Idoko
}

\author{
General Studies Unit, Air Force Institute of Technology, Kaduna, Nigeria. \\ *Corresponding author. Email: oyegid@afit.edu.ng/dejigideon@gmail.com
}

Copyright (C 2021 Idris and Oyedeji. This article remains permanently open access under the terms of the Creative Commons Attribution License 4.0, which permits unrestricted use, distribution, and reproduction in any medium, provided the original work is properly cited.

Received 10th September, 2021; Accepted 6th October, 2021

\begin{abstract}
The incessant xenophobic attacks of Nigerians and other foreign nationals in South Africa have generated a unique discourse in the Nigerian media and in fact, other mainstream media on the African continent and international scene. These attacks are viewed by the international community as incompatible with 21st century civility. This paper therefore, engages the reports of selected news media in Nigeria, South African and other media houses with a view to explicating the ideologies that underpin each report seeing through the insight of Van Dijk, Norman Fairclough and Ruth Wodak's models of Critical Discourse Analysis. A total of 10 report on the 2015-2019 xenophobia were purposively selected from the online outlets of these media houses. The study therefore found that the use of language by the Nigerian media shows that the polarisation tilted towards emphasising the positive 'in-group' description of the heinous acts visited on innocent Nigerians in South Africa whereas the South African and other news media brought to perspective the negative 'out-group' description of "some" Nigerians who are engaged in illegal businesses in their South Africa. The lexical choices contribute in significant ways to show the ideologies each reporters represent. The study submits that, these attacks by South Africans on fellow African Nationals are nefarious, iniquitous, atrocious and roguish perhaps because of their colonial experience.
\end{abstract}

Keywords: Critical discourse analysis, ideologies, South Africa, xenophobic attacks.

\section{INTRODUCTION}

The term xenophobia refers to a dread of anything unusual or alien. It is also used to express hate of outsiders and foreigners. This expresses itself in a variety of ways, including the relationships and views of various groups of people. Clearly, xenophobia is based on a sense of insecurity when foreigners are perceived to be taking over one's country (Ogunnowo and Joshua, 2019; Anyim et al., 2019). People care about an ethnic nationality's personal and collective secure identity; therefore, anything that violates this personal and collective view is odd and cannot survive the hatred stated on such entity. Xenophobia, as defined by Klande (2001) and referenced by UNESCO (2017, p. 3), is "an attitudinal orientation of hatred toward non-natives in a particular population". Socio-cultural background and exposure often account for the development of a people's attitude, and once an attitude has been established, the foundation for shifting views is limited. As a result, xenophobic conduct is founded on preexisting racial, ethnic, religious, cultural, or national prejudice. According to Mogokwu (2005, p. 6), xenophobia is represented in discriminating attitudes and conduct, and it often ends in violence, abuse, and the display of complete hatred for foreigners. Harris (2001) backs up this point of view by claiming that xenophobia is caused by a sense of superiority and a lack of intercultural knowledge.

South Africa's xenophobic assaults against other Africans are based on a deep fear of foreign domination, stereotypes and attitudes. According to Premium Times (2017, p. 2) cited in Oyedeji (2020), since 1994, there have been waves of xenophobic violence directed against Nigerians and other African citizens. The 2008 disaster killed 62 people in Johannesburg townships, majority of them Nigerians. Another assault was carried out on African immigrants in April 2015. This was exacerbated by a 
statement by the Zulu monarch, Goodwill Zwelithini, who complained that the presence of foreigners in South Africa is making life difficult. As a prelude to the declaration that all foreigners should return to their own nations, some of the millennial enacted laws that allow them to inflict harm and even to murder outsiders.

Nigerians and other African citizens were met with another vicious xenophobic assault in Pretoria, Freetown, and other areas of South Africa in early 2017 and previous years (Bello and Tunde, 2017). According to Solomon and Kosaka (2013, p. 5), "the expression of xenophobia weakens societal cohesiveness, peaceful coexistence, and good governance, as well as instituting a violation of human rights". Supposedly, these assaults have compelled Nigerians and other African nations to participate in media discourses that are heavily influenced by ideologies, notably those of socio-cultural affiliation and views (Bello and Tunde, 2017; Peterside et al., 2020; Sotonye and Tamunopubo, 2020).

Most researches on the South African xenophobic attacks concentrate more on policy issues and bilateral relations (Peterside et al., 2020; Sotonye amd Tamunopubo, 2020; Bello and Tunde, 2017). Their concerns revolve around how the attacks will affect the relations between Nigeria and South Africa. This study therefore explores how the lexical choices made by selected news media express bias and ideological meanings which show negative out-group polarity and positive in-group polarity of people belonging to different affiliations.

\section{LANGUAGE AND THE MEDIA}

There is a manifestation of discourse that is distinct and separate from other discourses. For example, legal speech, political discourse, and commercial discourse all communicate unusual information with inherent characteristics. Distinctive characteristics of media discourse have formed part of the elements that explain for diverse interpretation of this kind of discourse. According to Crystal and Deny (1969, p. 173) cited in Oyedeji (2020), everything that occurs in the newspaper cannot be homogeneous since newspapers are eclectic in character. As a result, the material supplied by the agency of language cannot be homogeneous in the creation of meaning via the newspaper. They communicate ideological meanings and how lexical items show ideological polarities along different affiliations, in this case, Nigerians and South Africans.

The medium of language allows for the transmission of information via the media. This involves the act of encoding and transmitting the information through a channel to the receiver, who decodes the information based on the given language components and contextual subtleties that trail the message. Language, according to Reah (1998, p. 55), as quoted in Ogungbe (2012), includes emotional and cultural loading. He goes on to say that if a society has low regard for certain groups, concepts, or beliefs, the language used to convey thoughts about those people, concepts, or beliefs will reflect that attitude. As a result, media stories covertly show admiration for some groups, ideas, or views while simultaneously denigrating certain beliefs from certain borders.

One important consideration to bear in mind while reading newspaper stories, according to Taiwo (2004), is prejudice. This is due to the fact that newspapers reflect a political or cultural worldview. Because newspapers are protected by the freedom of expression, journalists may exhibit prejudice toward certain individuals, locations, and organisations. This is evident in the usage of certain derogatory phrases which promote stigma.

\section{News report and communicative strategies}

News articles often begin with a title that is graphologically positioned at the top of the text. The headlines of news stories typically capture the attention of readers who are reading the news. The arrangement and visuals of headlines are stylistic in order to pique the interest of readers. The headline is followed by the author's byline. This is the news reporter's name. As previously mentioned, every reporter has an ideology that is expressed via phrases and lexical items utilised; regardless of how powerful this ideology is, it must reflect the ideology of the editorial policy. According to Babalola (2002), after reading the headlines, readers go on to the first paragraph, which contains the story's lead line. Most readers overlook other aspects of the narrative.

It is important to remember that news articles are framed, and various publications have different framing techniques. In news reporting, journalists are continually pushed to choose which facts to include and which to exclude, which lexical words to employ, which facts to highlight, what to foreground and what to background, and what the actual problem is (Gamson and Modigliani 1989). These communication techniques were used to provide a framework for the news article. The frame is designed to convey what newspaper editors considered essential. lyangar (1991, p. 369) distinguishes between two kinds of frames: episodic and thematic. While episodic deals with the chronological sequencing of events in a narrative, paying attention to occurrences that precede that event and give significance for the story, thematic frame concentrates on the broad picture of the incident without much regard for how it occurred.

\section{Critical Discourse Analysis}

Media discourse is a powerful source of influence for readers, and it is often characterised by prejudices and beliefs. As a result, these biases may be unmasked by a sophisticated theory, resulting in Critical Discourse 
Analysis (CDA forthwith). Critical Discourse Analysis is a multifaceted paradigm that focuses on uncovering power dynamics and domination in media texts. It focuses on defining and understanding linguistic diversity, communicative engagement, and social literacy and power problems (Wodak 2001, p. 13). According to van Dijk (1993), CDA is a discourse analytical research method that focuses on bringing to light how power, abuse, domination, and inequality are enacted, reproduced, and resisted in the social and political environment via text and conversation. CDA is defined as follows by Fairclough (1999):

... discourse analysis which aims to systematically explore often opaque relationships of causality and determination between (a) discursive practices, events and texts, and (b) wider social and cultural structures, relations, and processes; to investigate how such practices, events and texts arise out of and are ideologically shaped by relations of power and struggles over power; and to explore how the opacity of these relationships between discourse and society is itself a factor securing power and hegemony. (Pp. 132-133).

Several CDA models have been suggested, including those by Fairclough (1999), Hodge and Kress (1993), van Dijk (1993), van Leeuwen (1996), and Wodak (2001). The inclusion of appurtenances that explain the positive ingroup polarity and negative outgroup polarity with the specific goal of increasing favourable image to self through linguistic means is a common foundation for all of these methods to textual analysis. However, it is critical to emphasis the significance of context while doing textual analysis using CDA.

This textual approach is appropriate for this study because it has analytical tools that are used to show the lexical items that communicate power, abuse, dominance and express bias against people, idea and ethnic affiliations in texts and talks. Specifically, van Dijk (1998) helps to show the ideological polarities in the analysed data.

\section{THEORETICAL INSIGHT}

To deconstruct the ideological underpinnings present in news reports on South African xenophobia, a mix of three Critical Discourse Analysis models - Fairclough (1999), van Dijk (1993), and Wodak (2001) - were used.

According to Fairclough (1999), textual analysis, particularly media text, should go beyond what is reported, and a critical engagement should be sought to ascertain why specific elements have been used by newsmakers. This is only feasible and holistic if contextual socio-cultural concerns are brought to the forefront. Specific fundamenttal assumptions underpin certain discourse choices. These assumptions are never value-free or innocent; rather, they are ideologically motivated and driven. We may learn about societal processes as well as particular ideologies by examining the patterns of language. He believes in a "secret agenda". Thus, his three-dimensional framework description, interpretation, and explanation - helps in textual analysis. Halliday's systemic functional linguistics and the three analytical frameworks - ideational, interpersonal, and textual analysis - enable this (Kuo and Nakura 2005).

Van Dijk (1993) offers a plethora of accoutrements that are used to explain the many philosophies that underpin media reporting. These analytical techniques are used to classify diction choices, actors, augmentation, projected meaning, comparison, polarisation, embellishments, rhetorical sequences, and so on. According to him, news stories and other forms of writing are delicately structured to represent an idea. Everything done by people is tainted by ideology, depending on the viewpoint from which it is seen. The focus of this paradigm is ideological polarisation of representation. According to Van Dijk, speech has two polarities: positive in-group polarity and negative out-group polarity. This polarisation is crucial to this research because it dives into highlighting the manner in which Nigerian mainstream media ideologically positions her reporting on South African Xenophobia and other media outside Nigeria, particularly South African media. The portrayal of self and Others, Us and Them, is central to Van Dijk's concept of the ideological square.

Ruth Wodak's CDA Model stresses the connection between a text's social and historical context as a component that affects textual ideology. According to Wodak (2001), the discourse historical approach "provides a vehicle for looking at latent power dynamics and the range of potentials in agents, because it integrates and triangulates knowledge about historical sources and the backgrounds of the social and political fields in which discursive events are embedded" (Wodak, 2009, p. 38). Texts are created by the historical scope and vantage point of the text creator, which is often supported by different ideological elements derived from people's experiences. Wodak describes how to conduct a systematic qualitative analysis using this technique.

- the intertextual and interdiscursive relationship between utterances, texts, genres and discourses;

- the extra-linguistic social/sociological variables;

- the history and archeology of texts and organisations; and

- the institutional frames of the specific context of a situation.

These analytical frameworks are engaged to explore the ideologies, biases and lexical choices used for description and representation in the selected texts variously.

\section{METHODOLOGY}

This is a qualitative content analysis of selected reports of South African xenophobic attacks of between 2015 and 2019. The data are purposively selected from the Nigerian 
mainstream media and other media outside Nigeria. This is basically undertaken to explore how the choice of dictions, context, actors and frames represent an affiliation and/or express bias. It is vivid that media text is underpinned by ideologies which are often constructed through varying contextual and other social factors. This engagement therefore delves into $x$-raying the various factors that account for the description and representation that played out in the selected date. The theoretical insight outlined by the Fairclough's (1999), Van Dijk's (1993) and Wodak's (2001) models of Critical Discourse Analysis are deployed to analyse a total of ten (10) reports of the selected reports.

\section{ANALYSIS}

\section{Ideologies in Nigerian newspapers}

Text 1: attacks are just an excuse for crime! (Daily Sun, February 28, 2017)

The vicious attacks meted on Nigerians and other African nationals by South Africans are borne out of a thirst for crime. This headline from the Daily Sun succinctly expresses the psychological make-up of the South African experience. Also, the expression used showcases that committing crime has become an intrinsic part of the life of some South Africans. In fact, to them, it is a crime not to commit a crime. The lead line of this story, "It is becoming obvious that people in some areas carry out xenophobic attacks to commit crimes, "lucidly captures the fact that xenophobia, as widely transmitted by people, seems not to be the in-thing. It is used as a haven to commit crimes as reported by the news medium. The metaphorical import of the headline provided a basis for hypothesizing that South Africans visited the foreigners with threats, violence and killings not because they really desired to send them away but used that as a means to commit crimes.

The framing of this report clearly foregrounds crime as the in-thing. The use of this phrase in the report exemplifies the xenophobes' ideological background within a thematic frame. Attacks in the sense of violence have a negative connotation in a country which aims for the peaceful co-existence of both citizens and foreigners. It is no news that attacks both physically, emotionally, and psychologically constitute a threat to the social fibre and peaceful co-relationship among members of a community. Society in South Africa has for many decades experienced and still experiences attacks of various kinds. According to Wodak (2001), the historical purview of a people's constitutes a strong ideology, hence, the South African Xenophobia.

Text 2: Nigerians suffer fresh xenophobic attacks in South Africa (News Agency of Nigeria, February 19, 2017)

To the victims of these attacks, the use of words with negative connotations to describe the experiences of foreigners in South Africa is evident. Lexemes such as "suffer" and "attack" show outright condemnation of the acts of the South Africans. The headline is biased and full of presuppositions. It implies that a lot of Nigerians have suffered violence at the hands of South Africans. It also presupposes that the attacks are taking place in South Africa and not in any other country. The passivity of the structure further foregrounds the biasness of the headline. The passive structure also put Nigerians in South Africa at the mercy of the South Africans. While it is true that some notorious foreigners are being maimed in South Africa, the targets are not only Nigerians. The headlines, however, beginning with "Nigerians Suffer" did not actually capture the real situation in South Africa. Portraying South Africa in a negative light as the actors in the statement indicts all South Africans as attackers of fellow Africans and people capable of inflicting pain on fellow human beings.

Looking through the syntactic lens, the arrangement of the structure exemplifies an emotive mental process. The sensers designated as Nigerians are portrayed as being subjected to a process of suffering, and the phenomenon of xenophobic attacks is pluralised to show that the attack is not just something that happened once but a series of experiences that have brought the incessant attacks to a point of public discourse. In the report, one will find a lot of words emphasising the bad attitude of the South Africans. Looting, burning, injuring, attacking, criminals, and so on are examples of such words. They were used to emphasize the acts being perpetuated by the South Africans.

\section{Text 3: Buhari sympathises with embattled Nigerians in South Africa (Sahara Reporters, April 19, 2015)}

This report by Sahara Reporters online newspaper succinctly captures the reactions of the Nigerian president elect as at the time of these attacks. The use of an emotive expression "sympathises" to portray to readers what Nigerians are going through in South Africa. Sympathise is used when something grievous has happened to someone. This therefore presupposes that for Nigerians in South Africa to be sympathised with means that they are being inflicted. And the general situational knowledge that is cogent for the realization of meaning of this headline is that South African no longer wants strangers in their land. The inflammatory statement made by the king of the Zulus has been referenced ad nauseam by analyts that it gave these perpetuators of crimes the impetus to carry out criminal acts against foreigners. The "embattled Nigerians" further foregrounds ideologically the chauvinistic view of the headline.

In examining the lead paragraph of the report using Van Dikk's (1993) Ideological Square, there is a clear differentiation between the words that are used to describe the acts of the South Africans and those that are used to show the state of the victims. Lexical expressions that show out-group representation of South Africa are "violent attacks in South Africa...". That word connotes a negative 
representation of South Africans. The in-group lexical element as deployed in the text is"... commended the Nigerian government for taking steps to ensure the protection..." This expression shows up in-group representation. The report did not assert that the Nigerian government deployed troops to South Africa to defend Nigerians there or to lay siege to the country, which is the giant of Africa.

Text 4: Nigeria demands $A U$ action over renewed South Africa xenophobia (Premium Times, February 20, 2017)

This text presents an array of discourse which negates some of the views promulgated in previous statements by some SA government officials who have been silent for some time over the issue of xenophobia in South Africa. Ostensibly, this headline is a material process of doing and it indicates an action prone side which seeks a quick action against the activities of xenophobes who have legalized the killings of foreigners on their soil. The headline also brings to light the fact that the attacks are renewed periodically as the activities seem not to have been curbed by the relevant authorities in South Africa.

From this headline it can be critically deduced that the ideological underpinning for this text is first to inform people of the moves that the Nigeria government has made in protecting her people and secondly to affirm the veracity of the fact that foreigners are being killed in South Africa. African Union has the role of maintaining peace and order on the continent. Nigerian approached the AU because, as noted earlier, the SA government has refused to deal with the issue of xenophobia in South Africa.

Text 5: Xenophobia: South Africa slams Nigeria after envoys recalled (News Agency of Nigeria, April 26, 2015)

Text 5 presents what looks like a fall-out between South Africa and Nigeria. This is based on the premise that Nigeria has made many attempts to call the attention of the SA government to the horrendous killings that have incapacitated the free movement of Nigerians in South Africa. Thus, the Nigeria Government employs this means to register her grievances because of the unwillingness of the SA government to deal with the issue. Clearly, the structural configuration of the text exemplifies the verbal process of saying. However, the process "slams" is an expletive which is directed towards Nigeria for her microscopic symbolism, which can be interpreted as an attempt to express her dismay and dissatisfaction with South Africa. This symbolism therefore speaks volume.

The ideological import of this text is framed in a way that the validity of the existence of xenophobia is ascertained and the claim of South Africa's government on the nonexistence of xenophobia is punctured. This is obvious in the response of South Africa to the action of the Nigerian government.

\section{Ideologies in other news media}

Text 6: 'I saw the anger in my son's eyes' - antixenophobia protester (News24, March 09, 2017)

The perceptual experience of a South African mother of her son signalled by the word saw expresses a mental process of perception. The senser designated by I (Sindy Sibiya) is a domestic worker in South Africa. The process implied that she could really see the phenomenon of anger in her son's face. Again, this headline corroborates the very fact that quite a number of South Africans have strong indignation towards foreigners. This could be partly because of their apartheid experience in the hands of the British detractors. This report opens with "The office of the president refused to receive a memorandum from anti-xenophobia marchers at the Union Buildings on Thursday". It is mind-boggling to know that the presidency refused the anti-xenophobia memorandum which expects the government to enact strict laws against xenophobic attacks in South Africa. One would ask, could the government be supporting xenophobia?

While it is true that every nation comprises people of different characters, temperaments and world views, a number of South Africans display primitive actions which are incompatible with the 21st century demands on human rights and civility. However, well-meaning citizens of South Africa were quite critical of the killings; hence, they staged a protest to curb the continuous xenophobic attacks on foreigners. The outcome of the protest shows, perhaps by this statement, "To them it was a clear sign that immigrants were being used as scapegoats to hide the government's failures" that the government had something in the coffin. A preponderance of the use of active sentences in the report shows that specific actors were responsible for specific actions. According to Van Dijk's (1998) notion of ideological square, lexical items such as crime, president refused, scapegoats are clear examples of negative out-group description of the South African Xenophobes. Interestingly, this news item emanates from a South African newspaper outlet. This suggests ideologically that xenophobia is a primitive and barbaric engagement.

Text 7: Majority of South Africans are xenophobic: SAIRR (Reuters, March 14, 2017)

According to Halliday (2004) metafunction, the ideational function of this expression in the headline is the relational process of transitivity. Also, the expression is attributive. The majority of South Africans are in the process, and the attribute is xenophobic. This assertion was made by the South Africa Institute of Race Relations. This assertion seems like an overstatement. However, if this view emanates from an institute that represents the South African people and government, one can conveniently submit that there is a high probability that it is true. Every human action has a socio-cognitive import. Van Dijk 
(1993) submits that it is the integration of the interlocutors' personal/social beliefs, relationships, global societal structures, and evaluation prowess that accounts for "critical adequacy in the study of social problems" (p. 98). It is therefore critical to note again that the display of the South African experience historically does not stop at a discourse of hatred. It turned into a physical massacre of African foreigners.

The expression made by the king of the Zulus in April 2015 that foreigners should go back to their countries further substantiates the fact that even some South African elites are xenophobic. This statement has been quoted ad nauseam by analysts of the resurgence of this nascent, crude, archaic, and barbarous conception meted out on fellow Africans by South Africans.

\section{Text 8: Mbeki denies existing xenophobia problems in South Africa (South Africa Broadcasting Corporation, March 9, 2017)}

The headline brought to the fore conspicuously by the South African Broadcasting Corporation copiously represents an in-group polarity which is deployed to mitigate the global criticism that trails the xenophobic attacks meted on foreign nationals in South Africa. Thabo Mbeki, who is supposed to be a renowned politician in South Africa, having served as the second Post Apartheid President of South Africa, should know the history of the country and the predilections of his people. For Mbeki to deny the heavy presence of xenophobes in South Africa is a daylight robbery of the truth. The way in which this South African media outlet framed the news is ideologically motivated to prove a cheap point, which ultimately betrays the course of the role of the media in setting national and global agendas focused on human rights and civility.

To aver that there is nothing wrong with South Africans, as claimed by Mbeki and subsequently accepted as newsworthy by the SABC, presupposes that South Africans see the plundering of foreigners as normal and rational. A responsible statesman will critically underscore the issues and cautiously make statements to first cushion the effect of the acts and thereafter assail the perpetrators of the acts variously. The verbal process of "denying" with a speaker recognised as Mbeki has serious implications for the global community. Because, as at this time, a number of foreigners have been killed in South Africa on the premise of selling hard drugs and using their homes as brothels. This, however, does not justify the action of killing these foreigners.

\section{Text 9: SA government behind xenophobia - protesters (News24, March 9, 2017)}

This expression cryptically corroborates the views expressed in text 6 . This is because, the polarity of this tilts towards the negative out-group accusing the South African government of being behind the perpetrators of the xenophobic attacks on the foreigners in the Country. News24 captures this report because, all the efforts made by these protesters in seeing the SA Government to respond to their quandary proved abortive, in fact, they are usually disallowed from seeing any government officials by the military. This headline is therefore critically underpinned to communicate the fact that the action of the government is a microcosm of what one could tag negligence or failure in leadership. The general role of any responsible government is to protect her citizens both foreign and national citizens of a country.

On the contrary, the government may have no idea about the xenophobic attacks, but its refusal and unwillingness to decisively deal with the issue especially in responding to the plight of these protesters speak volumes. One can make a number of inferences from her failure to handle the issue. The government has no albatross to remain silent. The government has no alibi not to respond to the people. While this headline accuses the government, the ideological import shows that foreigners are being maimed unlawfully in South Africa without arresting the perpetrators.

\section{Text 10: Zulu king's advisers to investigate xenophobia claims (East coastal Radio, May 21, 2017)}

Again, this expression captured in this headline is a material process with a structural configuration of actors identified as Zulu King's adviser, the process as "to investigate" and the recipient as "xenophobia claims". Just like in text 6, some SA government officials do not believe that anything is wrong with the killings of foreigners on their soil. Their brutal past has perhaps made it look quite normal to kill without following any path of litigation. The use of "claims" here suggests that the Zulu King's advisers are yet to agree with the obvious and ear-ringing outcries of the foreigners in South Africa. It must be noted that the views of the king's advisers spring forth from the views the king has.

The bias expressed through this headline tilts towards portraying South Africa in a good light by making such an assertion that the news aired by media outlets are mere claims which have not been substantiated. This has therefore given effrontery to these xenophobes to further visit their atrocious and vicious activities on foreigners who are already incapacitated. They are incapacitated because the SA government has refused to deal with the culprits appropriately.

\section{FINDINGS}

Language in the media is not just an effort to record events; rather, it is framed with the intention of conveying prejudices, which are often reflected in the selection of lexical elements that are highlighted. Numerously, the 
phrases used by the Nigerian news media are based on an ideology of a people seeking freedom of movement and access to fundamental civil rights for her people in South Africa, as well as retribution for the atrocities committed against her people. This is illustrated by the phrases and careful selection of the class of words used to indicate displeasure by the Nigerian news media.

While certain South African news sources utilised words to communicate the truth that xenophobic assaults are a linguistic creation, the majority of Nigerian news outlets confirm the reality of the looting of Nigerians' lives and properties, particularly those of other foreign people. Texts $1,2,3$, and 6 are, for example, striking instances confirming the veracity of the slaughter of innocent life in South Africa. While these actions are universally denounced as incompatible with 21st century civil human rights postulations, the South African government has been lax in prosecuting the offenders. The South African government's stance has a negative impact on the continent. The media in that country plays an important role in setting the government's agenda.

It should be emphasised, however, that the language employed in these headlines has an ideology when seen from a social viewpoint. Almost all of the selected text drawn from South African news media used words with polarity tilts towards the positive in-group in order to mitigate and repair the negative face of South Africans, whereas Nigerian news outlets deploy lexical choices with polarity tilts towards the negative out-group, cryptically labelling South Africans as xenophobes and a people with aggressive countenance. The reaction of the South African government and its officials confirms that the perpetration of xenophobic assaults has become a regular routine in the lives of South Africans, stemming directly from their harsh colonial history. Critically, history affects human experiences, and this reality cannot be ignored in the face of South Africa's assaults on foreigners.

\section{CONCLUSION}

Media discourse is grossly ideological. This study has therefore demonstrated in a pedantic manner the various ideologies that undercut the representation of people and places in the analysed data. It is clear that people's action, expression and attitude are knitted with their experiences and worldview. The South African Xenophobic attacks on foreign nationals could be as a result of the brutal historical past of the South Africans. The experiences they have had in the hands of colonial detractors account for their display of fury and idiotic massacre on their fellow Africans and reports outside Nigeria are either indifferent or express outright displeasure of the attacks. The reports that emanate from the Nigeria scene of course expressed a negative out-group description of the xenophobes in South Africa. The study therefore recommends that news media outlets should go beyond reporting what is new and sensational to exploring ways in which issues that can lead to further breakdown of peace are reported in a way that solutions are thematised.

\section{CONFLICT OF INTERESTS}

The authors declare that they have no conflict of interests.

\section{REFERENCES}

Anyim, B. A. Chijioke, N., \& Anyim-Ben, F. (2019). Nigeria, Nigerians and xenophobic attacks; political and economic implications: A phenomenological approach. GNOSI: An Interdisciplinary Journal of Human Theory and Praxis, 2(2), 2229.

Babalola, T. E. (2002). Newspaper as instruments for building literate communities: The Nigerian experience. Nordic Journal of African Studies 11(3), 403-410.

Bello, I., \& Tunde, S. R. (2017). The implication of xenophobic violence on Nigeria-South Africa relations. Journal of International Studies. 13, 117-125.

Fairclough, N. (1999). Critical discourse analysis: The critical study of language. Longman.

Gamson, W. A. C., \& Modiglian, A. (1989). Media discourse and public opinion on nuclear power: A constructionists approach. American Journal of Sociology, 95(1), 1-37.

Harris, B. (2001). A foreign experience: Violence, crime and xenophobia during South Africa's transition, CSUR.

Halliday, M. A. K. (2004). An introduction to functional grammar (2nd Edition). Edward Arnold.

Hodge, R., \& Kress, G. (1993). Language as ideology. Routledge.

lyangar, S. (1991). Is anyone responsible? University of Chicago Press.

Mogokwu, M. (2005). African union: Xenophobia as poor intercultural information. Ecquid Novi 26 (1), 5-20.

Ogungbe (2012). Pragmatic acts in the news reports of some Nigerian newspapers. A PhD Thesis. University Of Ibadan.

Ogunnowo, O., \& Joshua, S. (2019). Xenophobic attacks in South Africa and Nigeria's foreign policy: Rethinking Nigeria's afro-centric foreign policy posture. Covenant University Journal of Politics and International Affair. 7(1), 1-16.

Oyedeji, G. A. (2020). An exploration of Pius Adesanmi column articles: A pragmatic stylistic approach. Lambert Academic Publishing.

Peterside, S. K., Ibietan, J., \& Deinde-Adedeji, O. (2020). Xenophobia and migrants' irritants in Nigeria-South Africa Relations: A discourse. International Journal of Innovative Social Science and Humanities Research, 8(4), 48-60.

Solomon, H., \& Kosaka, H. (2013). Xenophobia in South Africa: Reflections, narratives and recommendations. South African Peace and Security Studies, 2(2), 5-30.

Sotonye, B., \& Tamunopubo, B. (2020). Xenophobic attacks on Nigerians in South Africa: Ethical implications, and responses of the Nigerian government. International Journal of Multidisciplinary Research and Development. 7(2), 36-41.

Taiwo, R. (2009). Legitimization and coercion in political discourse: A case study of Olusegun Obasanjo address to the PDP elders and stakeholders forum. Journal of Political Discourse Analysis. 2(2), 192-204.

UNESCO (2017). International technical guidance on sexuality education: An evidence-informed approach. UNESCO. 
Van Dijk, T. A. (1993). Principles of critical discourse analysis. Discourse \& Society, 4(2), 249-283.

Van Dijk, T. A (1998). Ideology. A multidisciplinary study. Sage

Van Leeuwen, T. (1996). The representation of social actors. In Caldas-Couthard, C. R., \& Coulthard, M. (eds.). Readings in critical discourse analysis. London and New York: Routledge. Pp. 32-70.

Wodak, R. (2001). What CDA is about - a summary of its history, important concepts and its developments. In: Wodak, R., \&
Meyer, M. (eds.). Methods of critical discourse analysis. Sage. Pp. 1-13.

Wodak, R. (2009). Critical discourse analysis. In: Seale, C., Gobo, G., Gubrium, J. F., \& Silverman, D.(eds.). Qualitative research practice (pp. 197-213). Sage. 